\title{
ノート口紅の使用に関する研究
}

一一口紅の塗布方法差による塗布量, 残存量, 推定摂取量について—

\author{
加藤精二 佐野 功 北村義一
}

\section{Lipstick Use Studies}

Seiji Kato, Isao Sano and Yoshikazu Kitamura

は じめに

口紅が他の化粧品と異って唇に使用され, 食事の際に 体内に入り，その中に有機色素が含まれていると問題に されることがある。

口紅に使用される有機色素は厳選された法定色素で, 口紅中に最大でも $5 \%$ 程度含まれるに過ぎないが，一体 口中に口紅がぞの程度入るのか, それには, ぞの位唇に 塗布されるのか測定データが見られない。

口紅の塗布量は, 口紅の種類や塗布方法, 個人差によ って変化すると思われるので検討した。

\section{1. 口紅の使用過程での塗布量, 残存量, 推定摂取量について}

\section{$1 \cdot 1$ 測定条件}

測定対象 : 18才から 35 才迄の女性10名

測定環境 : 室温 $24 \pm 1^{\circ} \mathrm{C}$, 湿度 $50 \pm 5 \%$

口紅種類 : 軟らかいタイプ, 硬いタイプ, 重いタイプの 3 種類

測定項目 :

(1) 直接塗布量 : リップスティックで直接唇に塗布 した時の塗布量

（2）紅筆塗布量 : 紅筆によって唇に塗布した時の塗 布量

（3）ティッシュ押さえ塗布量：直接或は紅筆で辰に 塗布した後, ティッシュペーパーで軽く押えて

東京化粧品工業会技術委員会色素専門委員

東京都港区虎ノ閒 2 丁目 9 番 14 号

Tokyo Cosmetic Industry Association Color

Additive Subcommittee 2-9-14 Toranomon,

Tokyo

\section{過鄱な口紅を除去した後の塗布量}

（4）残存量 : 朝塗布した後, 夕方迄再塗布せず, 残 っていた口紅をティッシュペーパーで完全に拭 きとった時の取れた量

（5）推定撕取量：ティッシュ押さえ塗布量と残存量 との差

測定方法：

対象女性は唇に塗布してある口紅を測定者の立 ち合いのもと, クレンジングクリームを用いて完 全に拭きとった。

（1）直接塗布量: 塗布前のキャップを除いたリップ スティック本体の重量と塗布後の重量を秤量し差 をとる。

（2）紅筆塗布量 : 紅筆は各人使用のものを用い, 付 着していた口紅を拭きとり，95\%アルコールでよ く洗浄し, 一定になる迄, 乾燥した後, リップス ティックと一緒に秤量し，その紅筆でリプスティ ックから口紅をつけ, 唇に叙布後, 再びリップス ティックと一緒に秤量し，その差を算出する。

（3）ティッシュ押さえ塗布量：直接塗布量と紅筆塗 布量の測定の前に対象者個々にティッシュ押さえ の練習をし，その後，コントロールとして測定用 ティッシュペーパーの唇押さえを行って, 前後の 重量を秤量し，直接塗布量と紅筆塗布量の湘定を してから，実際にティッシュ押さえを行ってロ紅 の付着重量を直接塗布量及び紅筆塗布量から差し 引く。

（4）残存量：無揮発性クレンジング油を適量ティッ シュペーパーにつけて秤量したものを用い, 唇上 の口紅を完全に拭きとった後にこれを科量し、そ の増加量で表した。 


\section{$1 \cdot 2$ 測定結果}

Table-1 に示した。

直接塗布量，紅筆塗布量とも口紅のタイプによる差は 殆んどなく，9〜13mgの範囲であり，紅筆で塗布した方 が少し多いようであった。

ティッシュ押さえによって上記塗布量の 30 ～ $40 \%$ がと れ，ティッシュ押さえ塗布量は $6 \sim 7 \mathrm{mg}$ となる。

残存量は $2 \sim 3$ mgで, ティッシュ押え塗布量の30〜40 \%であった。

推定摂取量は $4 \mathrm{mg}$ 程度で塗布量の約 $60 \%$ となった。し かし，この值には飲食その他で器物等に対着した量も含 まれるので，実際はこれより少ない数值となるるのと考 えられる。

Table-1 口紅使用過程での塗布量の変化

\begin{tabular}{|c|c|c|c|}
\hline リップスティックの種類 & 軟かい & 硬 い & 重 い \\
\hline (1) 直接塗布量 $n=5$ & $9.3 \mathrm{mg}$ & $9.3 \mathrm{mg}$ & $9.0 \mathrm{mg}$ \\
\hline （2） 紅筆塗布量 $n=5$ & 10.8 & 13.0 & 10.7 \\
\hline 平均塗布量 $n=10$ & 10.1 & 11.2 & 9.9 \\
\hline (3) ティシュ押さえ & & & \\
\hline 後の塗布量 $n=10$ & 7.1 & 6.0 & 6.9 \\
\hline (4) 残 存 量 $n=10$ & 2.8 & 1.6 & 2.9 \\
\hline (5) 推定摂取量 $n=10$ & 4.3 & 4.0 & 4.0 \\
\hline (5)の(3)に対する割合 & $60.6 \%$ & $66.7 \%$ & $58.0 \%$ \\
\hline
\end{tabular}

\section{2. 顔料濃度の異なる 3 種の口紅の塗布量に ついて}

\section{$2 \cdot 1$ 測定条件}

測定対象：18才から38才の女性20名

測定環境：室温 $23 \pm 1{ }^{\circ} \mathrm{C}$ ，湿度 $60 \pm 5 \%$

口紅種類 : 顔料濃度 $1 \%$ (有機色素 $1 \%$ 以下)

$$
\begin{aligned}
& \text { " " } 6 \% \text { (有機色素 } 2 \sim 3 \%) \\
& \text { " " 10\%(パール入り, 有機色素 } 2 \sim 3 \\
& \% \text { ) }
\end{aligned}
$$

\section{測定項目}

(1) 直接塗布量

(2) 紅筆塗布量

\section{測定方法}

$1 ・ 1$ の（測定方法）と同様である。測定は直接塗布 量, 紅筆塗布量とも各々 10 人について, 顔料濃度の異な る 3 種類の口紅を測定者の立ち合いのもとに行った。

測定值は直接塗布及び紅筆塗布共, 顔料濃度間の平均 値差及び同濃度で塗布方法の異なる測定値の平均值差の
検定を行い解析した。

\section{$2 \cdot 2$ 測定結果}

測定值は Table-2 の通りであり, 顔料濃度の間, 直 接塗布或は紅筆で塗布した塗布量の間の平均值差の検定

\begin{tabular}{|c|c|c|c|c|c|c|}
\hline \multirow{2}{*}{$\begin{array}{c}\text { 顔料 } \\
\text { 濃度 } \\
\text { 個人 }\end{array}$} & \multicolumn{3}{|c|}{ 直接スティック塗布 } & \multicolumn{3}{|c|}{ 紅筆による塗布 } \\
\hline & $\begin{array}{c}\mathrm{A}_{1} \\
1 \%\end{array}$ & $\begin{array}{l}\mathrm{A}_{2} \\
6 \%\end{array}$ & $\begin{array}{c}\mathrm{A}_{3} \\
10 \%\end{array}$ & $\begin{array}{r}\mathrm{B}_{1} \\
1 \%\end{array}$ & $\begin{array}{l}\mathrm{B}_{2} \\
6 \%\end{array}$ & $\begin{array}{c}\mathrm{B}_{3} \\
10 \%\end{array}$ \\
\hline A & $5.3 \mathrm{mg}$ & $6.0 \mathrm{~m}$ & $\mathrm{~g} 6.4 \mathrm{mg}$ & $14.8 \mathrm{mg}$ & $17.5 \mathrm{mg}$ & $13.4 \mathrm{mg}$ \\
\hline B & 9.3 & 11.5 & 12.0 & 10.1 & 11.4 & 11.0 \\
\hline $\mathrm{C}$ & 13.0 & 14.8 & 14.4 & 9.2 & 12.8 & 13.0 \\
\hline $\mathrm{D}$ & 10.2 & 11.0 & 13.5 & 7.0 & 14.0 & 13.6 \\
\hline $\mathrm{E}$ & 11.9 & 11.5 & 12.8 & 9.5 & 10.1 & 12.3 \\
\hline $\mathrm{F}$ & 5.7 & 7.2 & 7.1 & 7.2 & 7.8 & 9.1 \\
\hline G & 13.4 & 13.1 & 17.2 & 7.9 & 7.7 & 7.2 \\
\hline $\mathrm{H}$ & 11.7 & 12.0 & 19.0 & 2.5 & 3.8 & 6.3 \\
\hline I & 6.3 & 6.1 & 8.7 & 6.0 & 5.5 & 5.7 \\
\hline $\mathrm{J}$ & 5.3 & 5.5 & 7.5 & 6.3 & 6.9 & 6.5 \\
\hline 平 均 & 9.21 & 9.87 & 11.81 & 8.07 & 9.74 & 9.81 \\
\hline
\end{tabular}
の結果は Table-3 のようである。

Table-2 顔料濃度の異なる口紅の塗布量

\begin{tabular}{|c|c|c|c|c|}
\hline \multicolumn{2}{|c|}{ 要因の関係 } & $\mathrm{t}$ 值 & \multicolumn{2}{|c|}{ 有意差の検定 } \\
\hline \multirow{3}{*}{$3-1$} & \multirow{3}{*}{$\begin{array}{l}A_{1}-A_{2} \\
A_{1}-A_{3} \\
A_{2}-A_{3}\end{array}$} & 2.28 & \multicolumn{2}{|c|}{ 危険率 $5 \%$ で有意 } \\
\hline & & 4.21 & " $1 \%$ & "I \\
\hline & & 2.70 & " $5 \%$ & $" 1$ \\
\hline \multirow{3}{*}{$3-2$} & $\mathrm{~B}_{1}-\mathrm{B}_{2}$ & 2.41 & " $5 \%$ & 11 \\
\hline & $\mathrm{B}_{1}-\mathrm{B}_{3}$ & 2.23 & " $5 \%$ & $" 1$ \\
\hline & $\mathrm{B}_{2}-\mathrm{B}_{3}$ & 0.12 & \multicolumn{2}{|l|}{ 有意でない. } \\
\hline \multirow{3}{*}{$3-3$} & $A_{1}-B^{I}$ & 0.72 & \multicolumn{2}{|l|}{ " } \\
\hline & $\mathrm{A}_{2}-\mathrm{B}_{2}$ & 0.08 & \multicolumn{2}{|l|}{ "I } \\
\hline & $\mathrm{A}_{3}-\mathrm{B}_{3}$ & 1.12 & \multicolumn{2}{|l|}{ "I } \\
\hline
\end{tabular}

Table-3 口紅㓌布量の平均值差の検定

直接塗布量, 紅筆塗布量とも測定 -1 の值と殆んど变 らず, 1 回当りの平均值は $8 \sim 12 \mathrm{mg}$ であった。

直接スティックを用いての塗布量と紅筆による塗布量 は顔料濃度が同じなら差はあるとは言えない（Table-3 の 3-3)。

顔料濃度が変っている口紅の塗布量の羑は, 濃度によ って変り，直接スティックで塗布した方が 3 種間に明ら かに差が多く(Table-3 の 3-1), 紅筆の場合は濃度が 1 
$\%$ の場合と $6 \%$ 及び $10 \%$ （パール入り）とでは差がある が，6\%と10\% (パール入り) の間では差はあるとは言 えない(Table-3 の 3-2)。

この実験で塗布量は顔料濃度によって変るが, 個人内 では差が少なく， 3 種間で最大 2 倍強であるが，個人間 では, 顔料濃度が同じでも大きく変り 10 人の間の最大值 と最小值では 5 倍以上の差がある。

Table-4 口紅の使用期間調查

\begin{tabular}{|c|c|c|}
\hline 使 用 期 間 & 人 & 割 \\
\hline 1 箇月 & 2名 & $0.4 \%$ \\
\hline 1 箇月～ $2 "$ & 15 & 2.7 \\
\hline $2 " \sim 3 "$ & 53 & 9.5 \\
\hline $3 " \sim 6 "$ & 147 & 26.3 \\
\hline 6 "I $\sim 1$ 年 & 200 & 35.7 \\
\hline 1 年以上 & 131 & 23.4 \\
\hline 不明 & 11 & 2.0 \\
\hline 合 & 559 & 100.0 \\
\hline
\end{tabular}

\section{3. ま め}

（1）女性が口紅を唇に塗布する時. 1 回の平均塗布 量は, 測定一 1 で $10.35 \mathrm{mg}$, 測定一 2 では $9.75 \mathrm{mg}$, 両者 を含めての全平均塗布量は $10.0 \mathrm{mg}$ となる 1 回の最大塗 布量は 19.0 m であった。

(2) 1 日当りの塗布量は塗布回数が通常 $3 \sim 4$ 回, 最多でも $5 \sim 6$ 回である。 $3 \sim 6$ 回として

(1) 平均的塗布の場合 $30 \sim 60 \mathrm{mg} / \mathrm{day}$

(2) 最大の塗布の場合 $57 \sim 114 \mathrm{mg} /$ day となる。

（3）一方, 口紅の使用期間調查 ${ }^{1)}$ Table-4 から平均 的使用者を最頻值 6 箇月, 多量使用者として最短期間 1 箇月の值をとり, 口紅 1 本の内容量を大き目の $4 \mathrm{~g}$ とし て, その内容量の $70 \%$ 程度を使用終了とし 1 日の塗布量
を算出すると，

(1) 平均的使用者 $16 \mathrm{mg} / \mathrm{day}$

(2) 多量の使用者 $93 \mathrm{mg} / \mathrm{day}$ となる。

これは今回の測定値からの計算より少し小さいが近い值 である。

（4）又, T G A で 222 名に一定期間使用させて, その減量から計算して出した 1 日当りの最大使用量は $73 \mathrm{mg}$ あるる2)。この值と今回の測定值から計算した 1 日 当りの塗布量と比較すると, 平均的塗布量 $60 \mathrm{mg} / \mathrm{day}$ よ り多く, 最大塗布で最多回数塗布量の $114 \mathrm{mg} / \mathrm{day} よ り$ 可成り少ない。

（5） 1 日当りの推定摂取量を測定 $1 \cdot 2$ から塗布量 の60\%になるといら数値を使って計算すると

(1) 平均的塗布の場合 $18 \sim 36 \mathrm{mg} /$ day

(2) 最大の塗布の場合 $34 \sim 68 \mathrm{mg} / \mathrm{day}$ となる。

從って, 平均的には $20 \sim 30 \mathrm{mg} / \mathrm{day}$, 最大でも $70 \mathrm{mg} / \mathrm{day}$ を越えることはないと考えられる。

\section{4. おわりに}

本稿は東京化粧品工業会技術委員会色素専門委員会で 計画し, 昭和52年 4 月から10月にかけて, カネボウ, キ スキーの各研究所で実施したデータをまとめたものであ って, ポーラ, 及びアイデアルの各研究所で実施した結 果も殆んどこれと合致していた。

\section{文献}

1）東京化粧品工業会, 口紅の使用調査, 1975年 6 月 対象：東京地区女性 800 名, 回収 559 名 $(70.0 \%)$

2) The Toilet Goods Association, Inc., Lipstick Use Studies, March 3, 1959. Entry No. 101, Color Additive Master File No. 9.

（昭和53年 3 月 31 日受理） 